
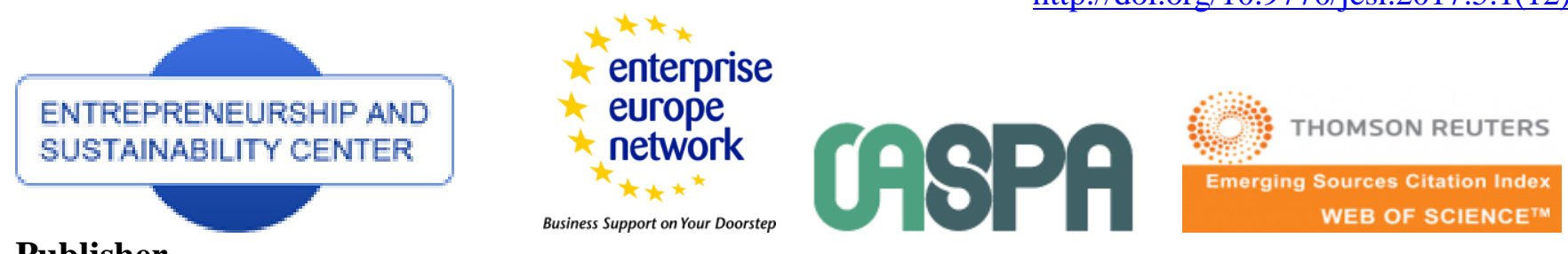

\title{
Publisher
}

\section{NETWORKING OF SMALL CITIES TO GAIN SUSTAINABILITY*}

\author{
Zhanna Mingaleva1, Marina Sheresheva ${ }^{3}$, Matvey Oborin ${ }^{2}$, Tat'yana Gvarliani ${ }^{4}$ \\ ${ }^{1}$ Perm National Research Polytechnic University (PNRPU), address Komsomolsky prospect 29, 614990 Perm,.Russia \\ ${ }^{2}$ Lomonosov Moscow State University, Faculty of Economics, address Leninskie Gory 1-46, 199911 Moscow, Russia \\ ${ }^{3}$ Perm Institute (branch) of the Plekhanov Russian University of Economics, address Boulevard Gagarina 57, 614070 Perm, \\ Russia \\ ${ }^{4}$ Sochi State University, address St. Sovetskaya 26a, 354000, Sochi, Russia \\ International Network Center for Fundamental and Applied Research, address St. Sovetskaya 26a, 354000 Sochi, Russia
}

E-mails: ${ }^{1}$ mingal1@psu.ru; ${ }^{2}$ m.sheresheva@gmail.com, ${ }^{3}$ recreachin@rambler.ru; ${ }^{4}$ antana-tata@mail.ru

Received 15 March 2017; accepted 20 June 2017

\begin{abstract}
The paper addresses networking as a basis for cooperation of small cities leading to more sustainable regional development at the city, regional, and federal level. It is shown that networking of cities can contribute to increasing sustainability in many ways. Still, additional research is needed to adjust best management practices discussed in the relevant academic literature to the peculiarities of transition economies. The objective of the research presented in the paper was to help regional and municipal authorities in the optimization of territorial development planning aimed at long-term sustainability. Research was carried out in Russia on an example of two regions, namely Perm Krai and Vladimir Oblast. The case study revealed that local authorities underestimate the potential of small cities in raising regional sustainability. Actually, a number of small cities in both regions have hidden competitive advantages but cannot realize them separately, whilst development of regional city networking is a fruitful approach to improve their socio-economic situation, and to boost sustainable regional development. Therefore, when planning regional development, federal and local authorities should regard the role of small cities, including disadvantaged and depressed ones, as potentially valuable members of a city network. Measures to embed small cities into different types of networks should be based on the thorough assessment of their resources, with the aim to develop collaboration of cities with mutually beneficial network externalities.
\end{abstract}

Keywords: sustainability, small city, networking, regional development, planning, specialization

Reference to this paper should be made as follows: Mingaleva, Z.; Sheresheva, M.; Oborin, M.; Gvarliani, T. 2017. Networking of small cities to gain sustainability, Entrepreneurship and Sustainability Issues 140-156. http://doi.org/10.9770/jesi.2017.5.1(12)

JEL Classifications: R11, R12, R13, R58

\footnotetext{
*This research was conducted with the financial support of Russian Science Foundation (project No. 17-18-01324 "Sustainable development of the territorial economy through networking of small cities and district centers")
} 


\section{Introduction}

The last decades have been characterized by the expansion of economics, politics and institutional relations (Vázquez-Barquero, 2003). In particular, collaborative networking on different levels, both in business and in state and municipal administration, is now attracting attention in many countries (Gemünden et al 1997; Nijkamp, 2003; Gustavsson et al 2009; Ge et al 2010), including emerging and transitional economies (Sheresheva, Peresvetov, 2012; Derudder et al 2013; Taylor et al 2014). The impressive development of some industries in BRICS countries is often attributed to the cluster policy conducted by governments with the aim to boost entrepreneurial innovation activity (Wolman, Hincapie, 2010; Bek et al 2013; Santana et al 2015), and networking of cities is expected to grow in importance as a way to sustainable regional development (Satterthwaite, 1997; Camagni, 2002; Campbell, 2013; Nijkamp, Perrels, 2014).

Still, not all the economies are equally successful in pushing forward networking and entrepreneurship in and between cities, and thus to ensure their sustainable development. In particular, Russia falls behind to get the effect from collaborative networking of municipalities, local communities and organizations, in contrast to many European countries (Gustavsson et al 2009; Campbell, 2013), as well as BRICS countries (Xu, 2008). Therefore, this study aims to shed light on the impediments and prospects of small Russian cities' sustainable development, with the main focus on networking.

In this research, two Russian regions were selected, namely Perm Krai and Vladimirsky Oblast. These regions were chosen for a number of reasons. First, they represent different parts of Russia. Perm Krai is located in the Kama River basin, close to Urals, while Vladimirsky Oblast is a Central Russia region. Second, the two regions have different economic potential, history and development dynamics. Third, the number of small cities is equal (18 in each region), their significance for the regional economy is quite high; their initial specialization is different, some cities being in good condition, some facing depression. Finally, there is much space for improvement, since there is a good potential for diversification and sustainable development of their economy.

This article is structured as follows. Section 2 presents an overview of the literature on the system planning and spatial planning approach in connection with network concept, as well as on small cities' networking as an important factor of sustainable regional development. In Section 3, prospects are discussed to plan and develop networking of small cities for sustainability in Russian regions. The results of a case study are presented in Section 4. Finally, conclusions and suggestions for future research are provided.

\section{Networking of cities and sustainable regional development}

During the last decades, there have been major shifts in cities' roles in securing sustainable regional development. As Jessop (1997) underlines, these shifts were also reflected in increased interest in, and emphasis on, the 'competition state' at the national (and, at least in Europe, supranational) level and the 'entrepreneurial city' at both regional and local levels. The understanding is growing that the prosperity of any region directly depends on the sustainable urban development (Wheeler, Beatley, 2014). This paradigm is perceived as improving the quality of life in cities, including ecological, cultural, political, institutional, social and economic components, without leaving a on the future generations (Jenks, Dempsey 2005; Hopwood et al 2005; Flint, Raco, 2012; Yigitcanlar, Teriman, 2015; Larson et al 2017). A large number of competitive smart cities of different size is now recognized as an important condition to address meta-issues of climate change, urbanisation, citizen engagement and resource efficiency (Taylor, 2005; Hollands, 2008; Angelidou, 2014; Daher et al 2017; García-Fuentes, De Torre, 2017; Taylor Buck, While, 2017). 
The International Journal

ENTREPRENEURSHIP AND SUSTAINABILITY ISSUES

ISSN 2345-0282 (online) http://jssidoi.org/jesi/

2017 Volume 5 Number 1 (September)

http://doi.org/10.9770/jesi.2017.5.1(12)

At present, cities are regarded as economic actors developing their own development strategy, competing between and cooperating with each other (Camagni, Capello, 2005). This view is consistent with the city network paradigm (Capello, 2002) in which it is justified that networking - intended in a micro-economic sense as cooperation among individuals, firms and institutions concerning collective action, public/private partnerships and the supply of public goods - "may become a scientific paradigm for interpreting the macroscopic spatial behaviour of collective agents like cities, competing and cooperating in the global arena where locations of internationally mobile factors (professionals, corporations, institutions) are negotiated and large territorial projects are decided" (Camagni, Capello, 2005: 498). Similar to cooperation and collective action of individual economic actors with common interest inside the city, common interest might be defined "through new urban governance tools" (Camagni, Capello, 2005) to the entire local community, as well as to groups of cities.

In this connection, Arnold et al. (2016) point out an important role of policy entrepreneurs - well-resourced and well-connected individuals - in advocating and securing the adoption of policies, including forming new mechanisms for building a desirable urban future. They underline that policy entrepreneurs are more successful when they have a greater number of sympathetic coalition partners. That means that entrepreneurial mind in contemporary city management is of crucial importance (Jessop, 1997), as well as readiness to network and build long-term relationships, taking into account the needs of all external and internal stakeholders, including entrepreneurs, local communities, tourists, investors, potential migrants, etc. (Anholt, 2007).

Jeong et al. (2015) examine a typology of network cities by linking a range of mobility environments to small and medium-size cities in a socioeconomically disadvantaged Dongnam region, Korea. They had shown that some socio-economically disadvantaged small cities in the region where mobility environments are relatively weak were excluded in forming urban networks. Therefore, functional linkage to the major cities and the expansion of passenger and cargo based links are of crucial importance for small cities that aim to gain sustainability through networking.

The possibility of using system planning tools to ensure sustainable development of cities is actively discussed in the framework of spatial planning approach (Runhaar et al 2009; Angelidou, 2014; Albrechts, 2015), as well as network concept (Campbell, 2013). There is a substantial body of research on the role of cities as "key nodes in an increasingly globalized economy" (Derudder et al 2013), based on Castells' argument for a network society that encompasses a "global network" of cities that cannot be reduced to "a few urban cores at the top of the hierarchy" (Castells, 1996). There is clear evidence now that networks of cities create a synergy, boosting both their own sustainable development, and regional economic growth (Meijers, 2005; Van Eck et al 2005; Van Oort et al 2010). Frenken and Hoekman (2006) analysed a set of regional economic indicators of European countries (EU25) and conducted a factor analysis of economic growth in 1088 regions of Western Europe. Using regression models, they had shown that regions with intensive networking of cities (of different size) demonstrated higher economic growth than those without networks of cities. The same conclusion was made by a number of researchers who studied networks of cities in Japan, Korea, China, and some other countries (Kwon, 2009; Sohn, 2011; De Vries, 2012; MOLIT, 2014).

Most studies on network interaction between cities and their impact on the regional economic growth tend to focus on global network of major cities, on mega-regions, and growth corridors (Castells, 1989; Batten, 1995; Jacobs, 2000; Taylor, 2004; Taylor et al 2002; Hall, Pain, 2006; Taylor et al 2008; Harrison, 2010), while the literature on the feasibility and importance of embedding small cities in networks remains scarce (Cross, 2001; Garcia, 2011; Dril et al 2016). 
At the same time, small and medium-sized cities are much more numerous than large ones; in the next decades, the world population will largely depend on small cities' growth rate and welfare, especially in developing countries. It is expected that in 2007-2025 the world urban population will increase by 1.3 billion people, in 20252050 by 1.8 billion more, with the highest forecasted growth in India (an increase of 261 million in 2007-2025, and of 377 million in 2025-2050) and in China (an increase of 197 million in 2007-2025, and of 205 million in 2025-2050). As a result, China and India will account for $36 \%$ of the entire urban population growth. This percentage is forecasted to be higher than the input of the next nine countries (Nigeria and DR Congo in Africa; Bangladesh, Indonesia, Pakistan and Philippines in Asia; Brazil and Mexico in Latin America; and the United States). It is expected that by 2025 there will be 48 megacities in the world but their joint share in the world urban population will remain only 7\%, while small urban centers are expected to grow fast. According to UN forecast, the number of people living in small cities will increase by almost 700 million, in medium-sized cities - by over 400 million, and in large cities (with 5 or more million inhabitants) - by 300 million. The spread of small cities where more than half of the world urban population is concentrated will further contribute to the emergence of new urban settlements (UN, 2008). As a result, sustainability of small cities is critical to well-being of any region in the world (Knox, Mayer, 2013).

Therefore, there is a need in additional research on the role of small city networking in connection with the issues of sustainable regional development. An important subject of study is planning and management of relationships between cities to improve the ability of all city stakeholders to achieve their aims, and to ensure joint prosperity in the long run. To address these gaps, we analysed the development state of small cities in two Russian regions, and proposed ways to "build bridges", to develop networking linkages, and to combine municipal resources and competencies for more sustainable regional development.

\section{Small cities in Russia: prospects of networking for sustainability}

In Russia, 70.8\% of all cities are small (with population number less than 50,000) (Rosstat, 2016). The number and share of small cities varies by region, but not significantly. As to the Perm Krai and the Vladimir Oblast, there are 18 small cities in, which is more than $70 \%$ of the total number of cities in both regions. To compare, in the Tula Oblast there are 13 small cities, or 68\% of the total number of cities (Rosstat, 2016).

In total, there are more than 780 small cities in Russia, extremely diverse in their current state. Many of them are unique in their history, cultural heritage, geographical position, and economic specialization. Some are quite successful in their development but there are also many depressive small cities, with low quality of life, lacking sufficient development conditions. This cannot be recognized as only Russian local specifics, since there is evidence that there are problems in

At the same time, the problems of Russian small cities are to a great extent the result of the post-Soviet decades, since no attention was paid to their development on the federal level. Such tendency to neglect the role of small cities was partly based on some modern theories of spatial planning and regional development which interpreted small cities as a deterrent for the sustainable regional development. Nowadays, both theory and practice prove that correct consideration of the role and place of small cities as network actors at the planning stage helps to combine their scarce resources with those of larger and more successful cities, to overcome negative trends in depressed small cities, and thus to boost sustainable regional development (Leigh, Blakely, 2016).

At present, a number of Russian researchers propose to abandon the idea of maximizing competition between cities and regions, which was widespread in the first post-Soviet decades, and to move from "the red ocean of bloody competition" (Kim, Mauborgne, 2014: ix) towards prioritizing coopetition strategy (Pasquinelli, 2013; 
The International Journal

ENTREPRENEURSHIP AND SUSTAINABILITY ISSUES

ISSN 2345-0282 (online) http://jssidoi.org/jesi/

2017 Volume 5 Number 1 (September)

http://doi.org/10.9770/jesi.2017.5.1(12)

Baggio, Sheresheva, 2014) in public administration and management. They underline that regional sustainability can be achieved through equalization socio-economic development of cities with different size and specialization within a single regional network, taking in account peculiarities of local institutional environment and existing local experience of spatial and socio-economic planning (Oborin, 2010; Meteleva, 2011; Dovbysh, 2016).

In Russia, to organize an effective planning process for creating a network that embrace cities of different size, a number of basic points should be ensured. Some are standard principles of planning network structure and mutual relationships, while others are based on local specifics.

First of all, it is necessary to take into account the historically conditioned environment for the socio-economic development of cities that are going to be network members. Huge geographical space, as well as XX century history of Russia, have led to the uneven distribution of transport connections in different regions. Many small and medium-sized cities do not possess sufficient transportation links with other cities, including administrative centres, even within the same region. In our research, we paid special attention to this point, since the local impact of passenger, cargo and migration flows on forming a network city within a region was approved to be of high importance (Jeong et al 2015). From our point of view, if the main goal is to gain regional sustainability, it doesn't make sense to create a network that consists solely of developed cities and excludes socio-economically disadvantaged settlements. In case they will be "left to themselves" and stay poorly connected to those cities that have entered the network, depressive tendencies may increase and lead to decrease in overall sustainability of a region.

There is evidence that sometimes the rapprochement with bigger cities or urban centers of a neighbor region appears to be the preferred path for small cities from a region where connections between such settlements are weak. Such "escape from own region" may be due to the shortsightedness of regional authorities that neglect of the interests of local small cities, but sometimes economic expediency may be the cause.

This evidence is important, since it questions some aspects of current norms accepted in public administration in Russia. Namely, KPIs of every region are now calculated and reported separately, just in the outdated logic of "competition, not cooperation". A number of institutional changes are needed to improve institutional environment. First of all, KPIs should be introduced on the federal level that will promote the development of mutually beneficial entrepreneurial networks and networks of cities, both within a region and interregional. Another conclusion that follows from the above is that it is necessary to focus on identifying strengths and weaknesses of each city in the region, to analyze the existing traffic flows between cities, and to plan the measures for optimization functional and transport links in compliance with the regional development strategy.

Secondly, regional and municipal authorities must take into account the existing structure of activities and resources allocation, as well as the potential for ensuring a balanced resources allocation and mutual benefits for network members, including prospective inputs and outputs of small cities located in the region. This point needs to be underlined, especially in connection with the need to understand more precisely what planning tools should be applied to ensure the evolution of low rank-size cities into an effective regional network, and what network structure may be considered as the most appropriate for this purpose.

In order to design and manage effective networking between cities on the basis of their functional specialization and resource allocation, spatial policy of local authorities should be based on elaborated mechanism enabling effective allocation and exchange of resources, competences, activities, and services, provided by each city, taking into account the interests of all stakeholders (Meijers, 2005; Green, 2007). As to preferred type of network, functional specialization planning of different cities and settlements within a regional network structure implemented on the basis of polycentric model is regarded by many authors as a better way to reduce 
transportation costs, to optimize the structure of resources' consumption and to enhance effectiveness of state support in transition economies (Mingaleva, Pazdnikova, 2009).

The rationale of directions and measures to increase the attractiveness of small and medium-sized cities as elements with prospective functional specialization in relevant fields of activity, determined in the framework of regional planning, can help to optimize the overall economic specialization of a region, to improve the transport infrastructure that allows reliable functional network linkages, and to align network activities with the main goals of regional strategy.

\section{Possible directions for networking of small cities: A case study of two Russian regions}

Two Russian regions, namely Perm Krai and Vladimirsky Oblast, were selected to conduct research on possible impediments, opportunities and directions for networking of small cities in Russia. There are 18 small cities in each of the two regions, some of them demonstrate good socio-economic conditions, some facing stagnation or depression. At the first stage, desk research and case study methods were chosen as the most appropriate. In this article, some preliminary results gained in 2017 are discussed.

The 18 small cities of the Perm Krai (Table 1) have been formed in the Soviet Union as centers for industrial production and mining. Many of them are single industry cities which faced degradation after the crash of the USSR. For example, Gubakha and Kizel, previously known as developed centers of coal mining, are now depressive territories. Alexandrovsk and Nytva still remain centers of engineering, although their socio-economic status and their attractiveness for people have deteriorated significantly. Krasnovishersk is a single industry city a regional center of the pulp and paper industry. It counts now for one of the most prospective small cities in the Perm Krai, gradually restoring its pace of socio-economic development. As a whole, small cities of the Perm Krai have a predominantly industrial specialization, while transport infrastructure is not well-formed.

Based on the case study data, 18 small cities of the Perm Krai can be conditionally divided into three main groups:

Group 1. Sufficiently developed cities: Alexandrovsk, Chernushka, Chusovoy, Dobryanka, Gremyachinsk, Gornozavodsk, Kudymkar,Vereshchagino.

Group 2. Conditionally disadvantaged cities: Chermoz, Gubakha, Okhansk, Osa, Nytva.

Group 3. Depressive cities: Cherdyn, Kizel, Krasnovishersk, Ochyor, Usolye.

The eight sufficiently developed small cities (group 1) are mostly single industry cities. There are several large enterprises in these cities that are quite successful in production of goods supplied not only for the Perm Krai and other Russian regions, but also for export. So, in Gremyachinsk there are two forestry enterprises Gremyachinskiy and PLPK, car accessories plant Autospetsoborudovanie, gas compressor station Gremyachinskoye. In Gornozavodsk there is cement factory Gornozavodskcement, a reliable supplier of all large building materials producers in the Perm Krai. In Alexandrovsk, there are two large enterprises: Alekstrom (pilot plant for the production of wall materials), and Aleksandrovsky Machine Building Plant that supplies mining equipment to different countries of Eastern Europe, Southeast Asia, and Africa. Vereshchagino, Kudymkar, Chernushka, Dobryanka, and Chusovoy are also quite promising in the corresponding areas of industrial specialization, as they have a diversified economy, growth potential in existing industries, and good transport accessibility. Dobryanka and Chusovoy also have a significant growth potential in tourism and recreation, primarily in ski tourism and training services for professional athletes. As an example, the Russian Championship of Snowboarding is held on 
the basis of the Takman ski resort in Chusovoy. Since there are different types of activity in these eight small cities, their population does not decrease, amounting to 35-45 thousand people.

Table 1. Economic specialization of small cities in the Perm Krai

\begin{tabular}{|c|c|c|}
\hline City name & Contemporary specialization & $\begin{array}{l}\text { Potential specialization } \\
\end{array}$ \\
\hline Chermoz & $\begin{array}{l}\text { Agriculture, industrial } \\
\text { production }\end{array}$ & Agriculture, industrial production, tourism and recreation \\
\hline Cherdyn & Industrial production & Industrial production, tourism and recreation \\
\hline Usolye & $\begin{array}{l}\text { Agriculture, industrial } \\
\text { production }\end{array}$ & Agriculture, industrial production, tourism and recreation \\
\hline Okhansk & $\begin{array}{l}\text { Agriculture, industrial } \\
\text { production }\end{array}$ & Agriculture, industrial production, tourism and recreation \\
\hline Gremyachinsk & Industrial production & $\begin{array}{c}\text { Tourism and recreation, transport } \\
\text { (developed automotive connections, two railway lines) }\end{array}$ \\
\hline Gornozavodsk & Industrial production & $\begin{array}{c}\text { Transport } \\
\text { (developed automotive connections to big regional cities, including } \\
\text { Perm, railway line) }\end{array}$ \\
\hline Alexandrovsk & Industrial production & $\begin{array}{c}\text { Transport, tourism and recreation } \\
\text { (developed automotive connections, route of regional significance: } \\
\text { Solikamsk - Chusovoy - Kungur) }\end{array}$ \\
\hline Ochyor & $\begin{array}{l}\text { Single industry city in a state of } \\
\text { depression }\end{array}$ & $\begin{array}{c}\text { Tourism and recreation } \\
\text { (poor transport accessibility) }\end{array}$ \\
\hline Krasnovishersk & $\begin{array}{l}\text { Single industry city in a state of } \\
\text { depression }\end{array}$ & $\begin{array}{l}\text { Tourism and recreation } \\
\text { (poor transport accessibility) }\end{array}$ \\
\hline Kizel & Industrial production & $\begin{array}{c}\text { Tourism and recreation } \\
\text { (automotive route of regional significance, railway connections to big } \\
\text { regional cities }\end{array}$ \\
\hline Nytva & $\begin{array}{l}\text { Single industry city in a state of } \\
\text { depression }\end{array}$ & $\begin{array}{c}\text { Tourism and recreation } \\
\text { (poor transport accessibility) }\end{array}$ \\
\hline Gubakha & Industrial production & $\begin{array}{c}\text { Industrial production, transport, tourism and recreation } \\
\text { (highly developed transport network: automotive \& railway } \\
\text { connections) }\end{array}$ \\
\hline Osa & Industrial production & $\begin{array}{l}\text { Industrial production, tourism and recreation } \\
\text { (poor transport accessibility) }\end{array}$ \\
\hline Vereshchagino & $\begin{array}{l}\text { Industrial production, } \\
\text { agriculture }\end{array}$ & $\begin{array}{c}\text { Transport, tourism and recreation, industrial production (The } \\
\text { intersection of the Moscow-Vladivostok railway and the regional } \\
\text { highways Ochyor- Vereshchagino-Siva) }\end{array}$ \\
\hline Kudymkar & Food industry & $\begin{array}{c}\text { Food industry, agriculture, tourism and recreation } \\
\text { poor transport accessibility) }\end{array}$ \\
\hline Chernushka & Industrial production & Transport, tourism and recreation, industrial production \\
\hline Dobryanka & Industrial production & Transport, tourism and recreation, industrial production \\
\hline Chusovoy & Industrial production & Transport, tourism and recreation, industrial production \\
\hline
\end{tabular}

Source: case study data

The five conditionally disadvantaged small cities Chermoz, Okhansk, Nytva, Gubakha, and Osa (group 2) are facing common structural problems. Financial difficulties of city forming enterprises are the main cause of socioeconomic instability in these cities. Nevertheless, their transport accessibility, cultural heritage and favorable 
ecological conditions give them good prospects in the field of tourism and recreation. This allows us to positively assess the future of these cities within the framework of their traditional specialization, supplemented by new directions of development.

For the five depressed small cities Cherdyn, Usolye, Kizel, Ochyor, and Krasnovishersk (group 3), the common negative features are bankruptcy of local enterprises, population outflow, degradation of industrial and social infrastructure. At present, it is impossible to restore the initial industrial specialization of these cities. The only possible solution is to find some new directions of development, better within a regional network of cities. For example, Krasnovishersk can become a start or intermediate point for a variety of tourist routes along the Northern and Subpolar Urals, while Kizel and Usolye can become industrial transport network members, with access to Perm, Solikamsk and Berezniki through Gubakha (see Fig. 1).

Our analysis has shown that the 18 small cities of the Vladimir Oblast can also be divided into three groups, with similar problems in each group:

Group 1. Sufficiently developed cities: Vyazniki, Kameshkovo, Kirzhach, Petushki, Raduzhny, Suzdal, YuryevPolsky.

Group 2. Conditionally disadvantaged cities: Gorokhovets, Kolchugino, Melenki, Pokrov, Sobinka, Sudogda.

Group 3. Depressive cities: Karabanovo, Kosterevo, Kurlovo, Lakinsk, Strunino.

Thus, we can conclude that some of the small cities in the Perm Krai and the Vladimir Oblast with historically developed industrial specialization are experiencing problems associated with an unfavorable socio-economic situation, the decline of industrial and social infrastructure, and the outflow of population into more developed cities, first of all to the regional centers. Since Vladimir Oblast is not so far from Moscow, many people from this region are also moving to the capital of Russia. In Perm Krai, the socio-economic difficulties of a number of small cities are additionally exacerbated by weak transport connections. Nevertheless, the historical, cultural, tourist and recreational potential of these cities, combined with a favorable ecological situation, allows the development of various types of tourism and sports activities, agriculture and food industry. In case of changing their functional specialization, these cities will possess more reliable basis to enter city network as valuable members. However, alignment of all stakeholders' interests is crucial, especially of citizens and local authorities, to ensure joint activities in achievement of this goal.

Based on the analysis of current and prospective specialization of small cities in Russian regions, three most applicable types of small cities' networking were identified with different core functional interaction, namely industrial transport network (ITN), agricultural network (ACN), tourist and recreational network (TRN).

1. Industrial transport network. The core functionality for ITN is transport infrastructure. Therefore, closeness of regional centers to the main railway lines and highways, especially federal and regional, is of key importance. Figure 1 shows the example of prospective ITN in Perm Krai. There are two triangles depicting transport links between the small towns Kizel-Aleksandrovsk-Gubakha (the first triangle), Gremyachinsk-GornozavodskChusovoy (the second triangle), both connected to the regional center Perm through large railway nodes (Chusovoy-Gubakha-Perm line). The third triangle includes three large transport nodes: Gubakha as the central city of the network, as well as two large cities Berezniki and Solikamsk, forming the core of the BereznikiSolikamsk industrial hub. There is also connection to Usolye, a small town for which tourist specialization is suitable due to its location on the Perm-Solikamsk railway line. 


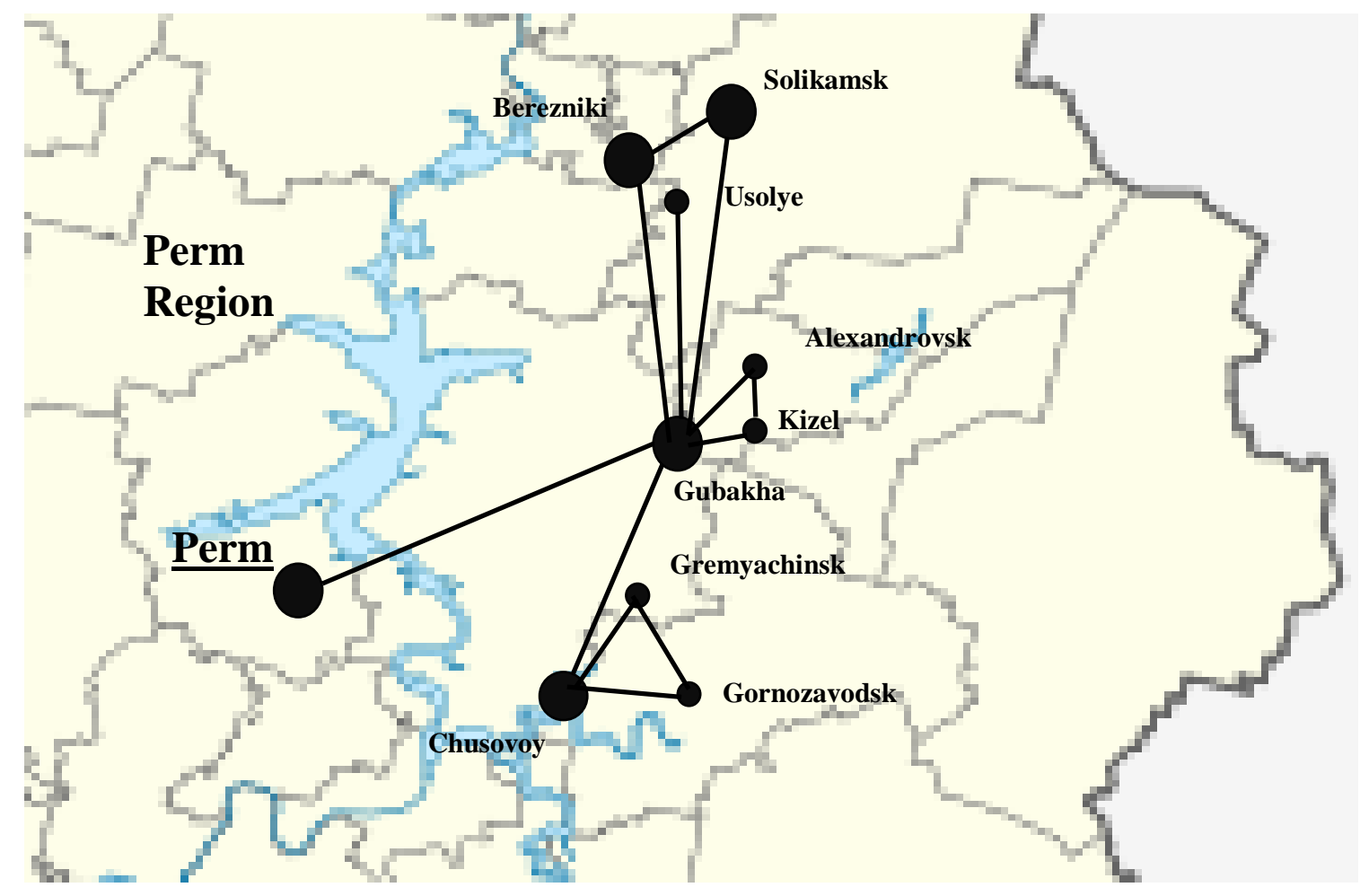

Fig.1. Prospective ACN in the Perm Krai

Source: overlaying graphic material on a geographic map available at: <http://www.mojgorod.ru/>

2. Agricultural network. ACN is based on sectoral specialization and covers spatially close regions and cities (in the Perm Krai these are Kudymkar, Oktyabrsky). Oktyabrsky district, with a center in the Oktyabrsky urban settlement (30 thousand citizens), may be regarded as an example of prospective ACN central node. Oktyabrsky district is located in the southeast of Permsky Krai, far from the regional center, at present with insufficient direct communication with Perm and other large cities of the region. At the same time, there is a railway station in the Oktyabrsky settlement. Oktyabrsky district borders in the north with the Ordinsky and Suksunsky districts of Perm Krai, in the west - with the Uinsky and Chernushinsky districts of the Perm Krai, in the south - with the Askinsky District of the Republic of Bashkortostan and in the east - with the Krasnoufimsky District of the Sverdlovsk Region. Most of these districts are known for their pronounced agricultural production structure. The Oktyabrsky is one of the leading agricultural districts in the Perm Krai. Therefore, it can become a transport hub center for ACN built by several districts of Perm Krai and neighboring agricultural districts from other Russian regions (Fig.2). 


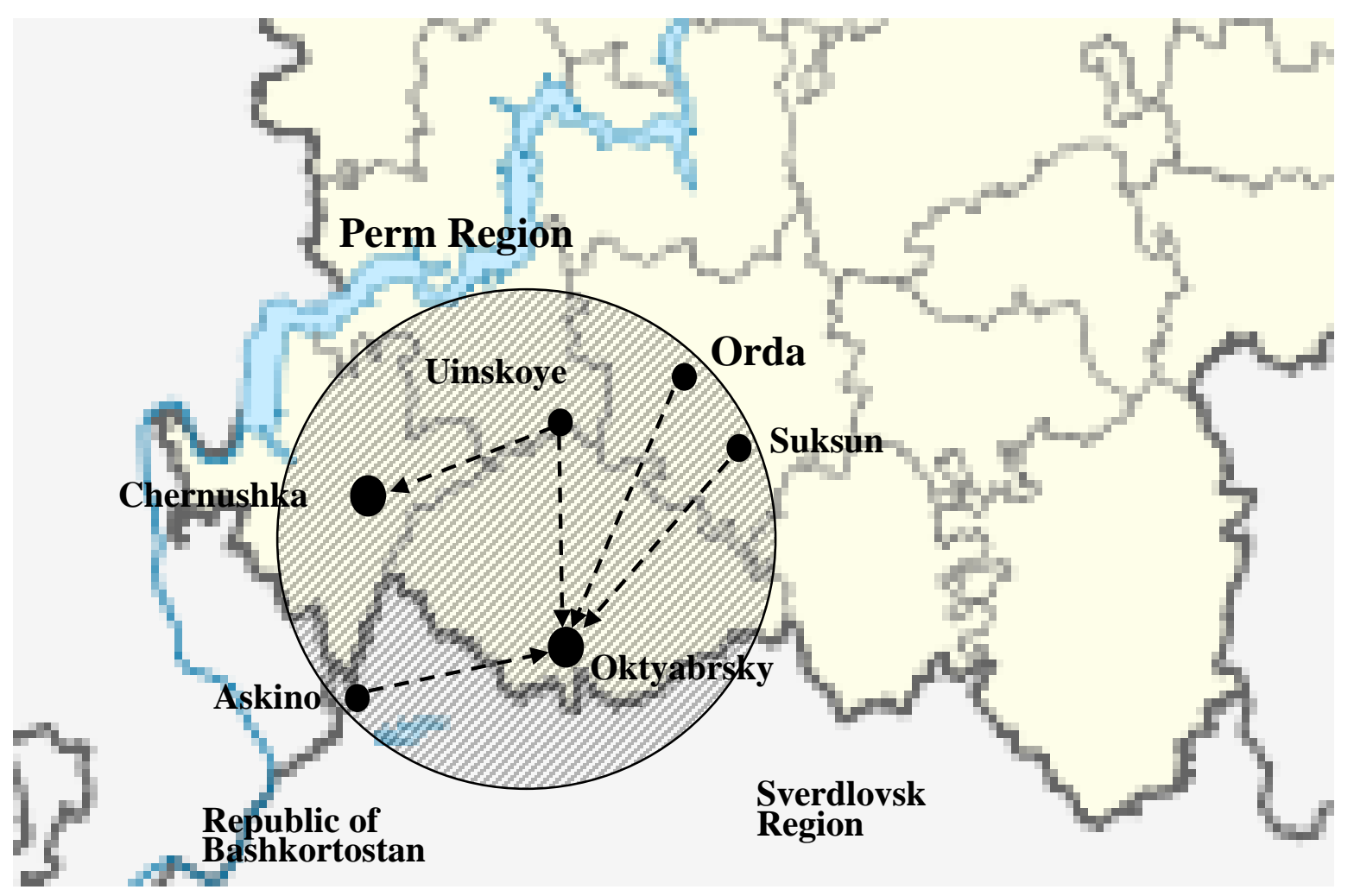

Fig.2. Prospective ACN in the Perm Krai

Source: overlaying graphic material on a geographic map available at: <http://www.mojgorod.ru/>

3. Tourist and recreational network. TRN is preferable within the framework of mixed specialization. This type of city network can embrace settlements situated quite far from each other but connected by common goal (Mingaleva, Bunakov, 2014; Sheresheva, 2016; Oborin, Sheresheva, 2017). As an example, the Vladimir Oblast is a key region for the Golden Ring of Russia - the main and most popular tourist route around historical provincial cities of central European Russia since Soviet times (the brand was founded in 1967). The regional center Vladimir and the small ancient city Suzdal are the central nodes of this route. There is also a registered tourist brand Small Golden Ring that connects a number of historical small cities of Vladimir Oblast. These cities possess developed tourist infrastructure and can themselves function as central points for various tourist routes. To improve socio-economic situation in a number of depressed cities in the region, such as Karabanovo, Kurlovo, and Lakinsk, it is possible to create a TRN with participation of these small cities (Fig.3). The possibility of such development is ensured by their cultural potential, as well as by their comparative proximity to the cities that are part of the Small Golden Ring. Thus, depressed small city Kurlovo is only 18 km from famous Russian city GusKhrustalny, a single industry city with historical glass and crystal plant that is now slowly restoring after difficult post-Soviet decades. The best decision for both cities could be the reorientation of their economic specialization into a tourist-recreational one, taking in account that railway station in Kurlovo ensures good transport connection. Another depressed small city Lakinsk is located on the Nizhny Novgorod-Vladimir-Moscow highway M7 and can become an important transport hub in the regional city network. 


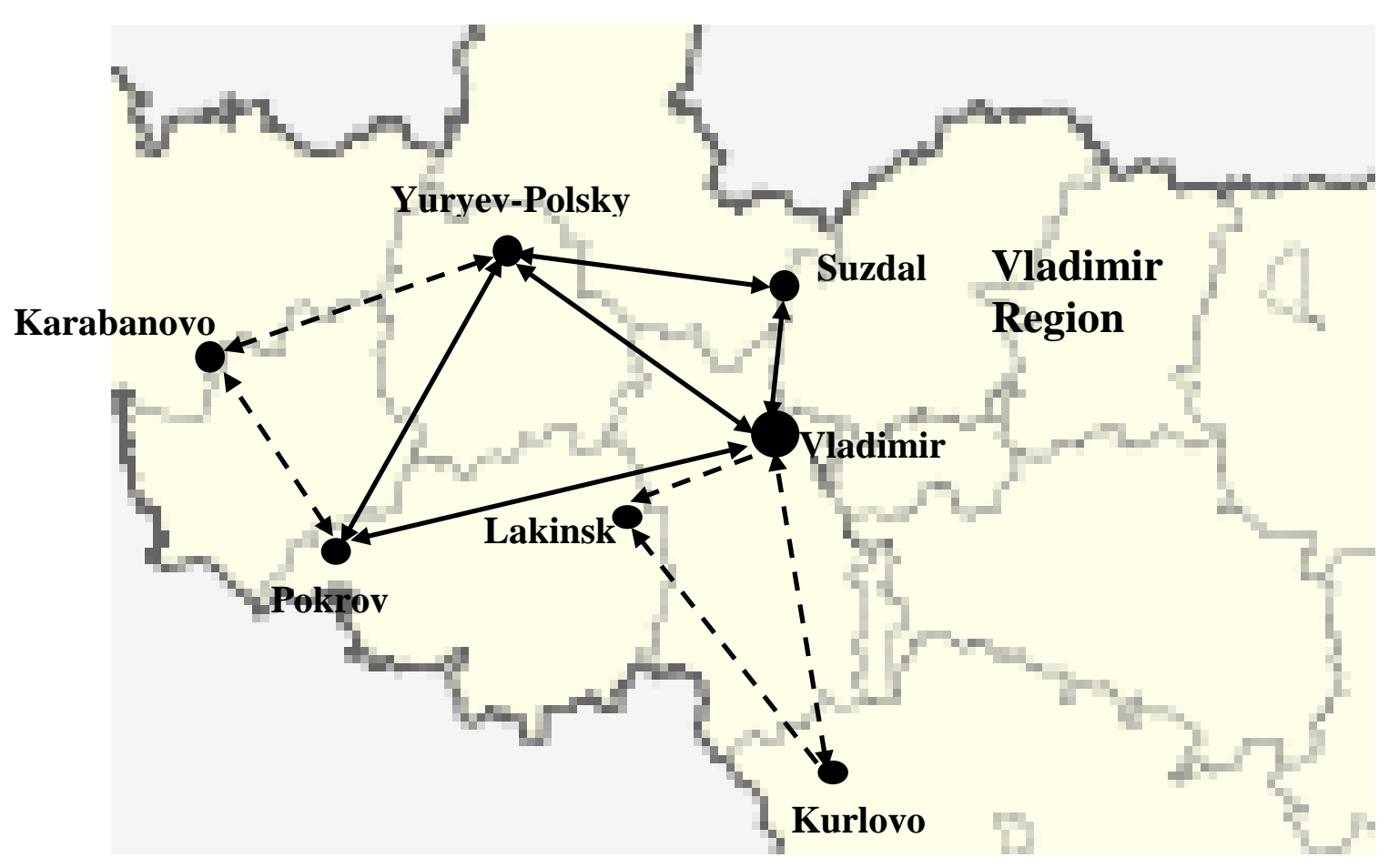

Fig.3. Prospective TRN in the Vladimirsky Oblast

Source: overlaying graphic material on a geographic map available at: 〈http://www.mojgorod.ru/>

Given that most of the small cities of the Vladimir Oblast have historical and cultural sights, we can conclude that tourism is one of the most promising areas for regional sustainable development. In addition, at present hospitality and catering infrastructure is growing fast in the Vladimir Oblast, as well as the infrastructure of medical and health tourism, active, agro-, gastro- and ecotourism, industrial tourism, pilgrimage, etc. Therefore, it is advisable to form new tourist routes covering small cities in the framework of TRN.

For the Perm Krai, it is advisable to create a TRN with the main focus on sports tourism (including speleotourism), historical and patriotic tourism, industrial tourism, pilgrimage, as well as medical and health tourism (Oborin et al., 2016). Transport accessibility and hospitality infrastructure are the main impediments to be removed for the successful TRN development in Perm Krai, while Vladimirsky Oblast has excellent transport connections, both within the region and with other neighboring regions.

\section{Conclusions}


The International Journal

ENTREPRENEURSHIP AND SUSTAINABILITY ISSUES

ISSN 2345-0282 (online) http://jssidoi.org/jesi/

2017 Volume 5 Number 1 (September)

http://doi.org/10.9770/jesi.2017.5.1(12)

This paper describes results of the study carried to investigate network cooperation of small cities as a prospective way to improve their socio-economic positions. Research was carried out in Russia, selecting two regions, namely Perm Krai and Vladimir Oblast. It addresses the capability of city network to enhance sustainable regional development in transition economy. The main conclusions are as follows.

Ensuring sustainable regional development assumes a thorough assessment of the resources of small cities, with the aim to reveal their potential as valuable network members, to define the adequacy of their contemporary specialization to the requirements of the entire region, and to choose the best ways to develop city network of preferred type. This requirement should be especially stringent for those cities that lag far behind the leading regional cities in terms of socio-economic status, growth potential, and attractiveness for city stakeholders. It is also necessary to forecast the network externalities, both positive and negative, including the possibility of strengthening the competitiveness of disadvantaged and depressed cities without damaging sustainability of more developed network members or significantly reducing the overall efficiency of the network.

Based on the assessment, regional and municipal authorities need to define the preferred network type, and to welcome development of clear norms and rules for the distribution of basic services and functional activities among all cities in such a network. At the same time, combining efforts and the distribution of functional activities does not mean abandoning the individuality of cities. The uniqueness of each city should be regarded as an additional contribution to the overall sustainable development of the region. From their side, even the smallest cities should position themselves not isolated from other administrative entities, but as part of collaborative network that contributes to the overall development of the region.

Effective strategic planning is of high importance, since it can significantly help in ex-ante alignment of network members' interests, and to define priorities of joint development. This can serve as a solid base for joint projects implementation, exchange best management practices, experience and resources, as well as mutually beneficial coordination of joint activities.

When planning a network, special attention should be paid pay to the balanced spatial development of the region as a whole by linking long- and medium-term plans, strategies and concepts of spatial development on the city, district, regional, and sometimes inter-regional levels. The coordination of general development plans with the plans of individual cities is particularly important. A special section should clearly define aims, directions and scope of interactions of every city with other cities in the network.

The demand for a strict interconnection of municipal and regional development plans significantly complicates all planning activities. However, it is essential to have a joint plan of networking within a region, consistent with the real capabilities and potential of cities, including the small ones, as a reliable basis for sustainable development.

\section{References}

Albrechts, L. 2015. Ingredients for a more radical strategic spatial planning. Environment and Planning B: Planning and Design, 42(3): $510-525$.

Anholt, S. 2007. Competitive identity: The new brand management for nations, cities and regions. Journal of Brand Management, 14(6): 474-475.

Arnold, G.; Nguyen Long, L. A.; Gottlieb, M. 2016. Social networks and policy entrepreneurship: How relationships shape municipal decision making about high-volume hydraulic fracturing. Policy Studies Journal. DOI: 10.1111/psj.12175 
Angelidou, M. 2014. Smart city policies: A spatial approach. Cities, 41: S3-S11.

Batten, D. F. 1995. Network cities: creative urban agglomerations for the 21st century. Urban studies, 32(2): 313-327.

Baggio R., Sheresheva M. 2014. Setevoj podhod v jekonomike i upravlenii: mezhdisciplinarnyj kharakter. Vestnik Moskovskogo Universiteta.. Serija 6. Ekonomika 2: 3-21.

Bek, M.A.; Bek. N.N.; Sheresheva, M.Y.; Johnston, W.J. 2013. Perspectives of SME innovation clusters development in Russia, Journal of Business \& Industrial Marketing, 28(3): 240-259.

Campbell, T. 2013. Beyond smart cities: how cities network, learn and innovate. London: Published by Routledge.

Camagni, R.; Capello, R. 2005. The City Network Paradigm: Theory and Empirical Evidence. Urban Dynamics and Growth: Advances in Urban Economics: 495-529. Available at: 〈 https://doi.org/10.1108/S0573-8555(2005)0000266017〉

Camagni, R. 2002. On the concept of territorial competitiveness: sound or misleading? Urban Studies, 13: $2395-2412$.

Capello, R. 2000. The city network paradigm: measuring urban network externalities. Urban Studies, 37(11): $1925-1945$.

Castells, M. 1989. The Informational City. Information Technology, Economic Restructuring, Urban-Regional Process, Basil Blackwell. Oxford: Published by Blackwell.

Castells, M. 1996. The Rise of the Network Society. Oxford: Published by Blackwell.

Cross, J. A. 2001. Megacities and small towns: different perspectives on hazard vulnerability. Global Environmental Change Part B: Environmental Hazards, 3(2): 63-80.

Daher, E.; Kubicki, S.; Guerriero, A. 2017. Data-driven development in the smart city: Generative design for refugee camps in Luxembourg. Entrepreneurship and Sustainability Issues, 4(3): 364-379.

De Vries J. 2012. The Randstad: in search of a metropolis for Netherlands (Randstad: à la recherche d'une métropole pour les Pays-Bas). In: Bulletin de l'Association de géographes français, 89e année, 89(4): 534-546.

Derudder, B.; Taylor, P. J.; Hoyler, M.; Ni, P.; Liu, X.; Zhao, M.; ... Witlox, F. 2013. Measurement and interpretation of connectivity of Chinese cities in world city network, 2010. Chinese Geographical Science, 23(3): 261-273.

Dovbysh, E.G. 2016. Evropa: novye realii uchastija gorodov v integratsionnyh protsessah. Mirivaja ekonomika i mezhdunarodnye otnoshenija 60(1): 93-102.

Dril N., Galkin A., Bibik N. 2016. Applying city marketing as a tool to support sustainable development in small cities: Case study in Ukraine. Transportation Research Procedia, 16: 46-53.

Flint, J.; Raco, M. (eds). 2012. The future of sustainable cities: critical reflections. London: Published by Policy Press.

Frenken, K.; Hoekman, J. 2006. Convergence in an enlarged Europe: the role of network cities. Tijdschrift voor Economische en Sociale Geografie, 97(3): 321-326.

Garcia, B. C. 2011. Small town China: Rural labour and social inclusion. Published by Taylor \& Francis.

García-Fuentes, M. A.; De Torre, C. 2017. Towards smarter and more sustainable regenerative cities: the REMOURBAN model. Entrepreneurship and Sustainability Issues, 4(3): 328-338.

Ge, B.; Hisrich, R. D.; Dong, B. 2009. Networking, resource acquisition, and the performance of small and medium-sized enterprises: an empirical study of three major cities in China. Managing Global Transitions, 7(3): 221-239.

Green, N. 2007. Functional polycentricity: a formal definition in terms of social network analysis. Urban Studies, 44(11): 2077-2103. 
Gustavsson, E.; Elander, I.; Lundmark, M. 2009. Multilevel governance, networking cities, and the geography of climate-change mitigation: two Swedish examples. Environment and Planning C: Government and Policy, 27(1): 59-74.

Hall, P. G.; Pain, K. (Eds.). 2006. The polycentric metropolis: learning from mega-city regions in Europe. London: Published by Routledge.

Harrison, J. 2010. Networks of connectivity, territorial fragmentation, uneven development: The new politics of city-regionalism. Political Geography, 29(1): 17-27.

Hollands, R.G. 2008. Will the real smart city please stand up? City: Analysis of Urban Trends, Culture, Theory, Policy. Action, 12(3): 303-320.

Hopwood, B.; Mellor, M.; O'Brien, G. 2005. Sustainable development: mapping different approaches. Sustainable development, 13(1), 3852.

Jacobs J. 2000. The Nature of Economies. New York

Jenks, M.; Dempsey, N. (eds). 2005. Future forms and design for sustainable cities. London: Published by Routledge.

Jeong, Y.-Y.; Moon, T.-H.; Han, J.H. 2015. A typology of network city in a socio-economically disadvantaged region, City, Culture and Society, 7 (3): 161-168. DOI: http://dx.doi.org/10.1016/j.ccs.2015.12.001

Jessop, B. 1997. The entrepreneurial city: re-imaging localities, redesigning economic governance, or restructuring capital. Transforming cities: Contested governance and new spatial divisions, 46: 28-41.

Kim, W. C.; Mauborgne, R. A. 2014. Blue ocean strategy, expanded edition: How to create uncontested market space and make the competition irrelevant. Boston: Published by Harvard business review Press.

Knox, P.; Mayer, H. 2013. Small town sustainability: Economic, social, and environmental innovation. Walter de Gruyter.

Kwon, O. H. (2009). Theoretical examination of network cities and application possibility for South-East Region in Korea. Journal of the Economic Geographical Society of Korea 12(3): 277-290.

Larson, L. R.; Lauber, T. B.; Kay, D. L.; Cutts, B. B. 2017. Local government capacity to respond to environmental change: Insights from towns in New York State. Environmental Management, 1-18.

Leigh, N. G.; Blakely, E. J. 2016. Planning local economic development: Theory and practice. Published by Sage Publications.

Meijers, E. 2005. Polycentric urban regions and the quest for synergy: is a network of cities more than the sum of the parts. Urban Studies 42(4): 765-781.

Meteleva, E.R. 2011. Ispolzovanie setevogo podhoda v tehnologii strategicheskogo upravlenija gorodskim razvitiem. Baikal Research Journal 2: 59-69.

Mingaleva, Zh.; Bunakov, O. 2014. Competitiveness assessment of Russian territories in terms of inbound tourism. Life Science Journal, 11 (SI 6): 318-321.

Mingaleva, Zh. A.; Pazdnikova N.P. 2009. Otsenka effektivnosti resursnogo obespechenija monitoringa tselevyh programm sotsialnoekonomicheskoga razvitija regionov. Ekonomika regiona, 4: 211-214.

Moi gorod. 2017. Narodnaja entsiklopedija gorodov i regionov Rossii. Vladimir. Available at: 〈http://www.mojgorod.ru/〉

MOLIT. 2014. Status of urban planning 2013. Korean Government: 3-6.

Nijkamp, P. 2003. Entrepreneurship in a modern network economy, Regional Studies, 37(4): 395-405.

Nijkamp, P.; Perrels, A. 2014. Sustainable cities in Europe. London: Published by Routledge. 
Oborin, M.S. 2010. Sistemno-dialekticheskaja metodologija (sistemnyi podhod) kak instrument issledovanija kurortno-rekreatsionnyh system raznogo ierarhicheskogo urovnya. Regional Research, 3: 54-61.

Oborin M.S.; Frolova N.V.; Nagoeva T.A.; Mingazinova E.R.; Artamonova O.A.; Vladimirscy E.V.; Kayachev A.P. Assessment of health resort potential of the region based on Perm Krai. Research Journal of Pharmaceutical, Biological and Chemical Sciences, 7(6): 26612669.

Oborin M.S.; Sheresheva, M.Y. 2017. The specifity of network-based business models in the tourist-recreational sphere. Upravlenets/The Manager, 4(68): 24-31.

Pasquinelli, C. 2013. Competition, cooperation and co-opetition: Unfolding the process of inter-territorial branding. Urban Research \& Practice, 6(1): 1-18.

Rosstat. 2016. Federal State Statistics Service. Available at: < http://www.gks.ru/>

Runhaar, H.; Driessen, P.; Soer, L. 2009. Sustainable urban development and the challenge of policy integration: an assessment of planning tools for integrating spatial and environmental planning in the Netherlands. Environment and Planning B: Planning and Design, 36(3): 417-431.

Santana, N. B.; Mariano, E. B.; Camioto, F. D. C.; Rebelatto, D. A. D. N. 2015. National innovative capacity as determinant in sustainable development: a comparison between the BRICS and G7 countries. International Journal of Innovation and Sustainable Development, 9(34): 384-405.

Satterthwaite, D. 1997. Sustainable cities or cities that contribute to sustainable development? Urban studies, 34(10): 1667-1691.

Sheresheva, M. 2016. Russian hospitality and tourism: what needs to be addressed? Worldwide Hospitality and Tourism Themes 8 (3): 380 396. DOI: 10.1108/WHATT-02-2016-0009

Sheresheva, M.; Peresvetov, S. 2012. Inter-firm relationships of Russian SMEs: A way to survive the crisis and to innovate. Journal of Entrepreneurship \& Innovation, 4(4): 1-19. Available at: < http://jei.uni-ruse.bg/Issue-2012/2012-JEI-001-Sheresheva-Peresvetov.pdf>

Sohn, J. Y. 2011. Network city as a new urban growth model: a review on its formation, spatial structure, management, and growth potential. Journal of Korean Geographical Society 46(2): 181-196.

Taylor Buck, N.; While, A. 2017. Competitive urbanism and the limits to smart city innovation: The UK Future Cities initiative. Urban Studies, 54(2): 501-519.

Taylor, P.J. 2006. Development as a 'monstrous hybrid': an essay on the primacy of cities in the expansion of economic life. Environment and Planning A, 38(5): 793-803.

Taylor, P. J. 2004. World City Network: A Global Urban Analysis, London: Published by Routledge.

Taylor, P. J.; Catalano, G.; Walker, R. 2002. Measurement of the World City Network. GaWC Research Bulletin. Globalization and World Cities Study Group, GaWC.

Taylor, P. J.; Derudder, B.; Hoyler, M.; Ni, P.; Witlox, F. 2014. City-dyad analyses of China's integration into the world city network. Urban Studies, 51(5), 868-882.

Taylor, P.J.; Evans, D.M.; Pain, K. 2008. Application of the Interlocking Network Model to Mega-City-Regions: Measuring Polycentricity Within and Beyond CityRegions. Regional Studies, 42 (8): 1079-1093.

UN. 2008. OON obnarodovala novye dannye o tempah urbanizatsii $v$ stranah mira. Available at: <http://gtmarket.ru/news/state/2008/04/10/1668>

Van Eck, J. R.; Daalhuizen, F.; Van den Broek, L.; Van Oort, F.; Raspe, O. 2005. The Randstad as a network city. 45th Congress of the European Regional Science Association. on Land Use and Water Management in a Sustainable Network Society. August 23-27. Amsterdam, The Netherlands. 
The International Journal

ENTREPRENEURSHIP AND SUSTAINABILITY ISSUES

ISSN 2345-0282 (online) http://jssidoi.org/jesi/

2017 Volume 5 Number 1 (September)

http://doi.org/10.9770/jesi.2017.5.1(12)

Van Oort, F.; Burger, M.; Raspe, O. 2010. On the economic foundation of the urban network paradigm: spatial integration, functional integration and economic complementarities within the Dutch Randstad. Urban Studies 47(4): 725-748.

Vázquez-Barquero, A. 2003. Endogenous development: Networking, innovation, institutions and cities. London: Published by Routledge.

Wheeler, S. M.; Beatley, T. (Eds.). 2014. Sustainable urban development reader. London: Published by Routledge.

Wolman, H.; Hincapie, D. 2010. Clusters and cluster-based development: A literature review and policy discussion. Washington, DC: George Washington Institute of Public Policy (GWIPP).

Xu, J. 2008. Governing city-regions in China: Theoretical issues and perspectives for regional strategic planning. Town Planning Review, 79(2-3): 157-186.

Yigitcanlar, T.; Teriman, S. 2015. Rethinking sustainable urban development: towards an integrated planning and development process. International Journal of Environmental Science and Technology, 12(1): 341-352.

\section{Aknowledgements}

This research was conducted with the financial support of Russian Science Foundatio (project No. 17-18-01324 "Sustainable development of the territorial economy through networking of small cities and district centers")

Dr Zhanna MINGALEVA is Professor of Economics, Director of the Research Center for Sustainable Development and Innovation Processes, Perm National Research Polytechnic University, Russia. Editor-in-chief of the academic journal Ars Administrandi. Her research have been published in more than 450 journal articles, books, and conference papers, in Russia, USA, Canada, Germany, France, Japan, UK, Italy, Austria, Australia, Poland, Bulgaria, Ukraine. Her research interests are: technological and structural modernization of economy, innovative development, strategic planning and forecasting, interaction of authorities and entrepreneurial structures, including private-public partnership, regulation of entrepreneurial activity.

ORCID ID: orcid.org/0000-0001-7674-7846

Dr Marina SHERESHEVA is Professor of the Department of Applied Institutional Economics, Director of the Research Center for Network Economy, Head of the Laboratory for Institutional Analysis, Faculty of Economics, Lomonosov Moscow State University, Russia. She raised her qualification in USA, Canada and Europe in various institutions, including such as IESE Business School, Bologna University, Harvard Business School, and University of California, Berkeley. Her research have been published in the Industrial Marketing Management, Journal of Business and Industrial Marketing, Journal of Historical Research in Marketing, Worldwide Hospitality and Tourism Themes, and in other academic and professional journals, monographs and conference proceedings. Her research interests are: business networks, management, international marketing strategy, relationship marketing, new institutional economics, experience economy, hospitality and tourism.

ORCID ID: orcid.org/0000-0002-8153-7111

Dr Matvey OBORIN is Professor of the Department of Economic Analysis and Statistics, Perm Institute (branch) of the Plekhanov Russian University of Economics, Russia. His research results have been published in more than 395 journal articles, textbooks and monographs. His research interests are: health tourism, spa services, healthcare management, regional economics, sustainable development, urban development, marketing, financial management, financial analysis.

ORCID ID: orcid.org/0000-0002-4281-8615 
The International Journal

ENTREPRENEURSHIP AND SUSTAINABILITY ISSUES

ISSN 2345-0282 (online) http://jssidoi.org/jesi/

2017 Volume 5 Number 1 (September)

http://doi.org/10.9770/jesi.2017.5.1(12)

Dr Tat'yana GVARLIANI is Professor of the Department of Finance, Credit and World Economy, Sochi State University, Head of the Laboratory of the International Network Center for Fundamental and Applied Research. Her research results have been published in more than 280 publications, textbooks and monographs. Her research interests are: insurance, taxation, state and municipal finances, public sector economics, budgeting, financial analysis, tourism economics.

ORCID ID: orcid.org/0000-0002-4273-7526

Register for an ORCID ID:

https://orcid.org/register

Copyright ( $) 2017$ by author(s) and VsI Entrepreneurship and Sustainability Center

This work is licensed under the Creative Commons Attribution International License (CC BY).

http://creativecommons.org/licenses/by/4.0/

(c) (i) Open Access 